\title{
Impact of Sustainable Development of Coastal Areas and Small Islands in Makassar
}

\author{
Nur Khaerah $^{1 *}$, Nursaleh Hartaman ${ }^{2,3}$, and Miftahul Rahman ${ }^{3}$ \\ ${ }^{1}$ Universitas Muhammadiyah Makassar, Indonesia \\ ${ }^{2}$ Universitas Muhammadiyah Makassar, Indonesia \\ ${ }^{3}$ Pusat Penelitian Ilmu Sosial dan Humaniora Kontemporer, Indonesia
}

\begin{abstract}
Makassar City is a national strategic project development area, namely the construction of the Makassar New Port with the value of the Cooperation contract with Royal Boskalis of 75 million Euros. According to the government's expectation, Makassar New Port (MNP) can increase import-export activities in eastern Indonesia. Therefore, this study aims to analyze the impact of economic, socio-cultural, and environmental or ecological aspects. The method used is descriptive qualitative and the data obtained were analyzed using Nvivo12 Plus software. The results of this study found that marine sand mining has an impact and risk of environmental damage, such as decreased environmental carrying capacity, reduced natural resources, biodiversity, and weakened ecosystem integrity. These environmental changes greatly impact the productivity of fish income for fishermen. Fishermen's catch decreases, of course, this has something to do with changing social and economic conditions of fishermen. The phenomenon that is born is a disharmony that is very prone to causing quarrels in the household. While the economic impact, recorded a total loss of 1,043 fishermen from Kodingareng consisting of Traditional Fishing Gear, fishing rods, nets and arrows reached 80.4 billion rupiahs
\end{abstract}

\section{Introduction}

Indonesia is a maritime country and the largest archipelagic country in the world consisting of 17,508 islands. Indonesia has an area of 5.8 million $\mathrm{km} 2$, about $70 \%$ of its territory is a sea with a coastline of $81,000 \mathrm{~km}$ or the second-longest in the world after Canada, and an ocean area of about 3.1 million $\mathrm{km} 2(0.3$ million $\mathrm{km} 2$ of territorial waters and 2, 8 million $\mathrm{km} 2$ of archipelagic waters). This condition makes Indonesia dubbed as a maritime country with the most productive marine wealth seen from the large potential of its coastal and ocean resources [1-4].

Coastal areas and small islands in Indonesia experience many problems, one of which is due to inequality in their management. Due to the tendency of scarce land resources, the basic target of Indonesia's economic development will rely on the coastal zone and small islands and their sources. If it is not accompanied by the application of appropriate management policies, it can reduce the ability of coastal ecosystems and small islands in the provision of sustainable natural resources [5-7]

\footnotetext{
*Corresponding author: nurkhaerah@unismuh.ac.id
} 
Makassar City is one of the areas whose coastal areas and small islands have the potential for sustainable economic impacts. The total area of Makassar City is approximately $175.77 \mathrm{Km} 2$ of land and includes 11 islands in the Makassar Strait plus a water area of approximately $100 \mathrm{Km}$, is a flat coastal area with a slope of $0-5$ degrees to the west, flanked by two river mouths, namely the River Tallo which empties into the northern part of the city and Jeneberang River which empties into the southern part of the city.

This city has a few problems in realizing sustainable-oriented development. In recent years, Kodingareng Island has become a topic of discussion among NGOs and environmental activists. Kodingareng Village is part of the administrative area of Sangkarrang District, Makassar City. Kodingareng Village consists of two islands, namely Kodingareng Lompo Island and Kodingareng Keke Island. It covers an area of +48 ha and a height of 1.5 meters above sea level. On this island, there is a national strategic project, namely the development of the Makassar New Port, which was initiated by PT Pelindo and carried out by one of the world's largest dredging companies from the Netherlands named Royal Boskalis with a contract value of 75 million Euros. The government predicts that MNP can increase export-import activities in eastern Indonesia, thereby boosting the economy in eastern Indonesia. To supply the reclamation material, the dredging of sea sand was carried out by the ship "Queen of the Netherland" with a length of 230.71 meters and a width of 32 meters [8].

The problem that then arises is that this development does not pay attention to sustainable aspects. The sea sand mining (Spermonde Block) is right in the fishing area of Kodingareng Island fishermen such as Copong Lompo, Copong Ca'di, Bonema'lonjo, and Pungangrong. This greatly impacts the sustainability of three aspects in the concept of sustainable development, namely the economic, socio-cultural, and environmental preservation or ecological aspects $[9,10]$.

Significantly, coastal areas and small islands have financial benefits for a country's economy, but it may result in neglecting the future of coastal areas and small islands that are not socially and environmentally sustainable. Economic development activities in sustainable development are not prohibited, but it is necessary to pay attention to the sustainability of other aspects, such as the rate (level) of development activities not exceeding the carrying capacity of the natural environment. Sustainable coastal areas and small islands can be realized if their potential resources are used without giving a worse impact on nature, humans, and other systems [11-13].

\section{Method}

This study used a qualitative descriptive method and the data obtained were analyzed using the Nvivo12 Plus software. In addition, analyze and describe the impact of the construction of the Makassar New Port, Kodingareng Island, Makassar City based on a zoning system using theories and concepts related to sustainable development. Research data that has been collected through the media and interviews and then processed through Nvivo, data is matched with the research indicators that have been determined. The coding process is adjusted to the theory used. Classification of data as a data coding translation process, classification process using Nvivo cross-tabulation, cross-tabulation as a comparison process for each data. The last stage in the nvivo analysis process is the display of data in the form of graphs and tables, the analysis model in Nvivo is called a five-step analysis [14]. 


\section{Results and Discussion}

Kodingareng Island, which is located in the Makassar City area, was chosen as the location for the development of the Makassar New Port, which was initiated by PT Pelindo. This project is projected to be the largest port in eastern Indonesia with an area of 1,428 Ha. The presence of Makassar New Port as a strategy in increasing export-import activities in the eastern part of Indonesia, thus boosting the economy in eastern Indonesia. However, the other side of the impact of this development is that it results in environmental degradation, Socio-Cultural Change, and the Fisherman's Economy.

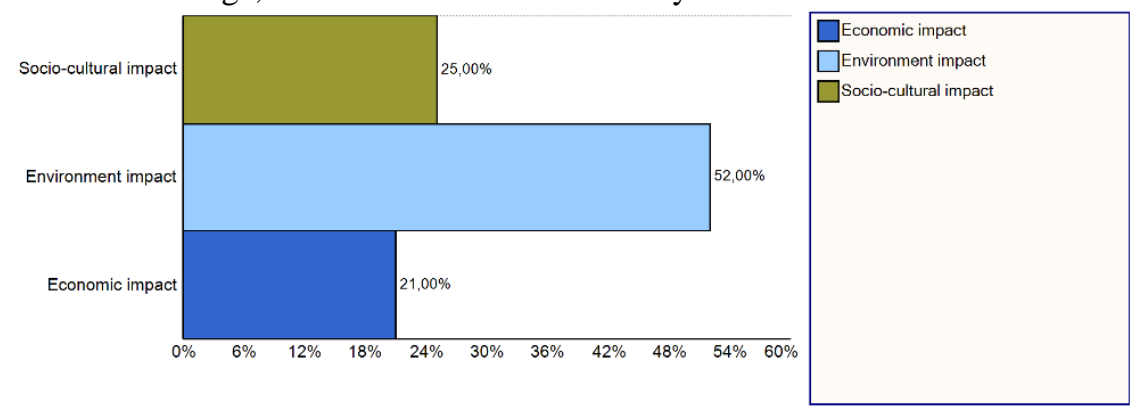

Fig. 1. the impact of the development of Makassar New Port

The biggest impact of the Makassar New Port development is on the environmental aspect. Then socio-cultural, then economic aspects. This problem is the basis for civil society organizations to advocate, with the hope of rescuing coastal areas and small islands to become sustainable. Three main pillars are mutually sustainable, namely economic aspects, social sustainability, and environmental sustainability.

\subsection{Environmental Impact}

From the search results, the stakeholders involved in the development of the Makassar New Port are PT Pelindo IV, which is the party most responsible for the impact of this MNP development. Then the Governor of Prov. South Sulawesi Nurdin Abdullah (which is currently deactivated), then the ESDM South Sulawesi Province and the Minister of Energy and Mineral Resources (ESDM).

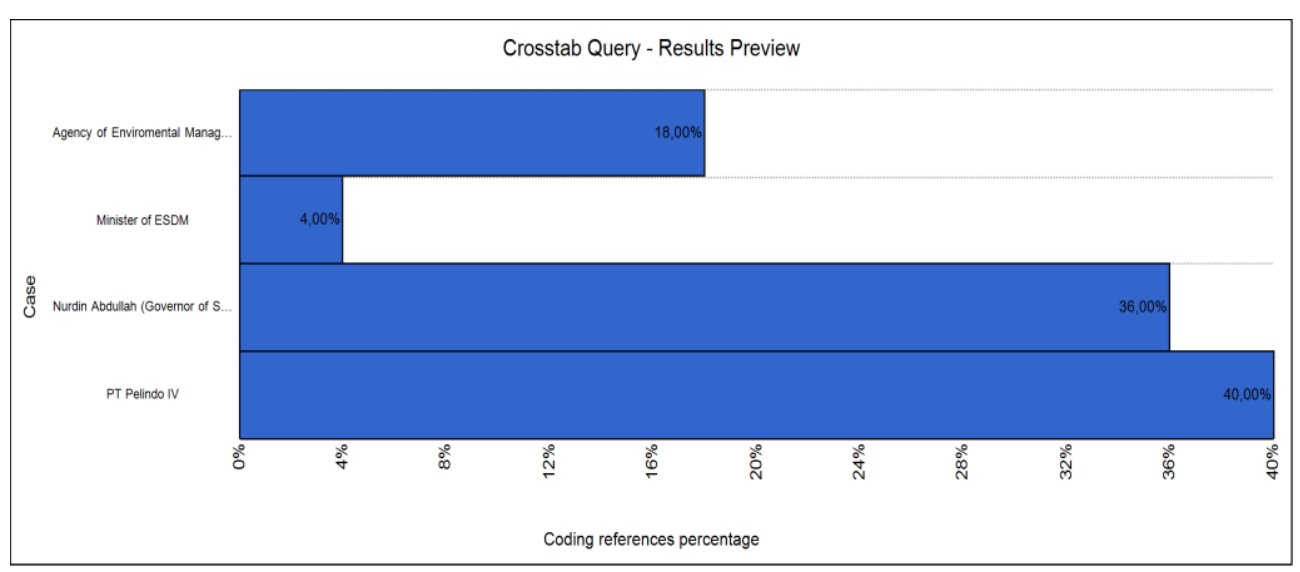

Fig. 2. actors involved in the MNP development plan 
PT Pelindo IV said that the sand mining location has been stipulated in Regional Regulation Number 2 of 2019 concerning the Zoning Plan for Coastal Areas and Small Islands (RZWP-3K) of South Sulawesi Province. It has also fulfilled legal aspects such as Environmental Impact Analysis, Port Master Plan (RJP), and Reclamation. Other preparations such as mitigation and attention to environmental aspects have been strictly controlled.

However, the facts on the ground show that marine sand mining activities have an impact and risk on environmental damage, such as: decreased environmental carrying capacity, reduced natural resources, biodiversity loss, and weakened ecosystem integrity.

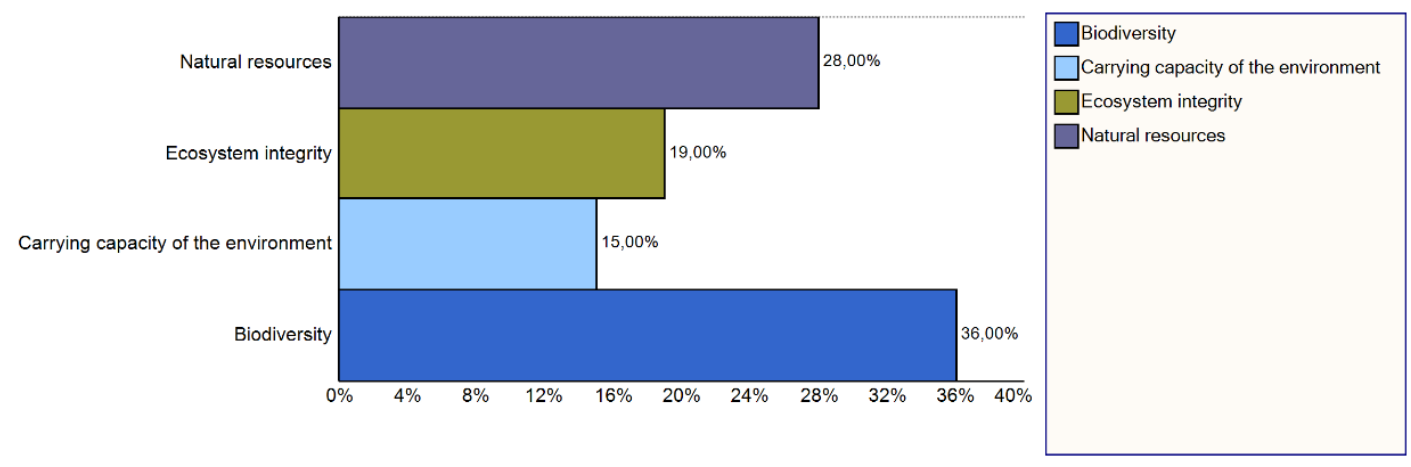

Fig. 3. Environmental/ecological impacts of MNP development

The environmental damage in question, such as the destruction of coral reefs, the depth of the seawater is increasing, the seawater becomes cloudy, the height of the waves is getting higher, and the waves are also getting bigger. According to the fishermen of Kodingareng Island, currently, abrasion is a real threat that is starting to lurk. These environmental changes greatly impact the productivity of fish income for fishermen.

Table. 1. Impact of environmental damage on fishermen's catch, [8]

\begin{tabular}{|c|c|}
\hline 2019 (Before Mining) & 2020 (After Mining) \\
\hline Archer Fisher & Archer Fisher \\
\hline Bui-Bui Fish 20 box/day & Bui-Bui Fish 1 box/day \\
\hline Tenggiri Fish 40 /day & Tenggiri Fish 1-2 /day \\
\hline Fishing Rods and Nets & Fishing Rods and Nets \\
\hline Katombo Fish 10 Gabus/day & Katombo Fish (-) \\
\hline Fishing & Fishing \\
\hline Squid $20 \mathrm{Kg} / \mathrm{Hari} /$ night & Squid $20 \mathrm{Kg} /$ day/night, and Not Even There \\
\hline Tenggiri Fish $10 /$ day & Tenggiri Fish 1 sampai 2 /day \\
\hline Traditional Fishing Gear & Traditional Fishing Gear \\
\hline Lure Fish100 box/ night & $\begin{array}{l}\text { Lure Fish } 2 \text { box/ night dan and Not Even } \\
\text { There }\end{array}$ \\
\hline Layang Fish 100 box/ night & Layang Fish 100 box/ night \\
\hline Sibula Fish 100 box/ night & Sibula Fish 100 box/ night \\
\hline Banyara Fish 20 box/ night & Banyara Fish 20 box/ night \\
\hline
\end{tabular}

Therefore, in 2020 until now, several civil society organizations such as the Indonesian Forum for the Environment (Wahli), the Mining Advocacy Network (Jatam), and the People's Coalition for Fisheries Justice (Kiara) and those who are members of the National Coalition to Save the Indonesian Seas are still actively assisting residents. Kodingareng Island. This action is consistently carried out to demand the government to stop and revoke the sea sand mining permit conducted by PT Boskalis. 


\subsection{Socio-Cultural Impact}

MNP development activities do not only have an impact on environmental and economic aspects, but also have a social impact on the lives of island communities including; on issues of basic human needs, population stability, local community participation in decision-making, and cultural diversity.

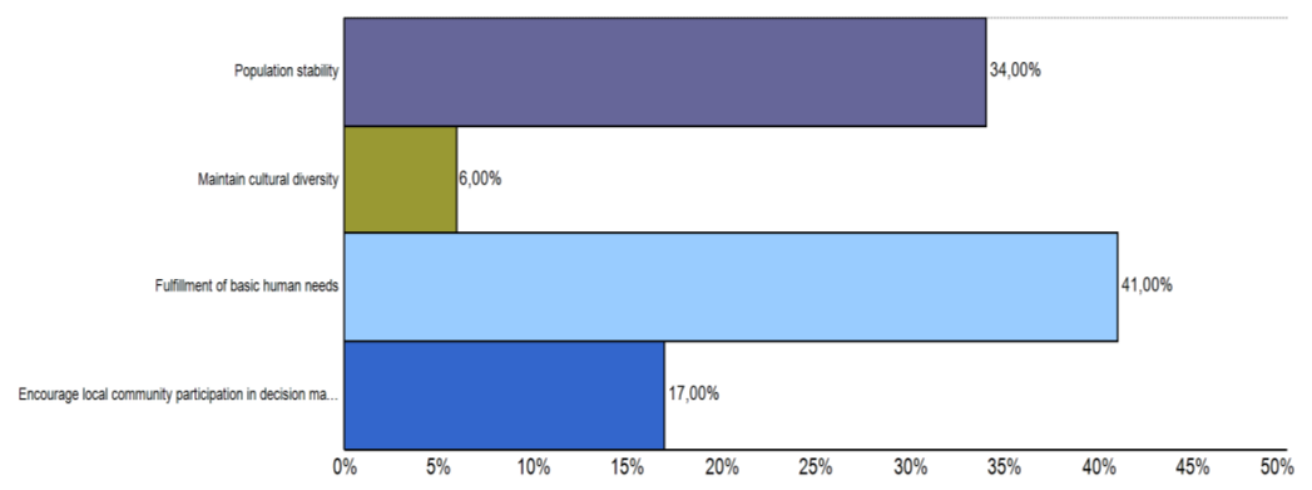

Fig. 4. Environmental/ecological impacts of MNP development

From the results of interviews with informants, researchers found a social fact that the decline in the quantity of fish caught by Kodingareng fishermen affected social conditions, including family life. The demands of living expenses and household needs, as well as the needs of children, become a burden.

Finally, it affects household conditions that start to feel less harmonious. To help their husbands' economy (as fishermen), most of the women in Kodingareng try to find additional income, up to loans to survive. Suffering, anxiety, and sadness began to be felt since the existence of sea sand mining activities in fishing areas. As an interesting conclusion, one of the fishermen said that if their livelihood is damaged, their hometown is no longer crowded, because this village is no longer able to generate or provide money, it is difficult to make a living or income.

\subsection{Economic Impact}

MNP development is an effort to protect the national economy. This MNP is carried out in three stages, each stage is divided into Packages A, B, C, and D. In phase I A, which was built from 2015 to 2018, the wharf has obtained a total investment for infrastructure and superstructure of IDR 2.51 trillion. This project forms the basis for sustainable economic development, but will only support the national economy.

Expectations of national economic growth, but ignore the local economy. Fishermen and women on Kodingareng Island are the objects affected by the existence of MNP because around $90 \%$ of the 4,500 residents of Kodingareng depend on marine activities and products (fishing profession). 


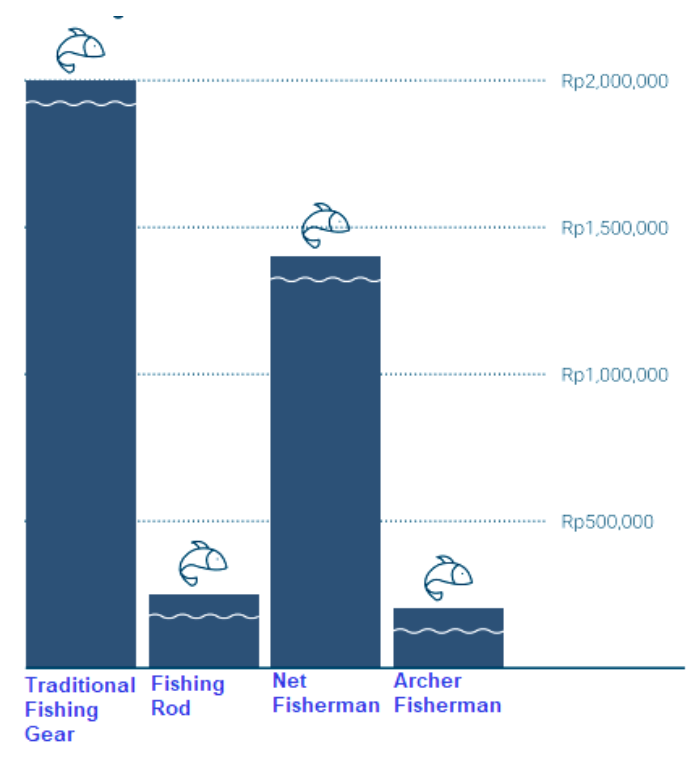

Fig. 5. The average loss of fishermen per day after the sea sand mining. [8]

Data obtained from the research results of the Save Spermonde Coalition [8], for approximately 257 days since the Queen of the Netherlands ship owned by PT Royal Boskalis was active in Spermonde waters and carried out sea sand mining, the Save Spermonde Coalition recorded a total loss of 1043 fishermen Kodingareng consisting of Traditional Fishing Gear, fishing rods, nets, and archers reached 80.4 billion rupiahs. Before the sea sand mining activity as a supporting activity for the construction of the Makassar New Port, the average fisherman could earn an income ranging from Rp. 200,000 to Rp. 2,000,000 per one livelihood. In total, it reaches Rp9,100,000 while the cost of capital and daily living reaches Rp6,617,500 per month. However, since the sea sand mining activity operates in the fishing area, the monthly income of fishermen is only around $\mathrm{Rp}$. 875,000. This amount is not proportional to the amount of capital expenditure for household needs, which is IDR 3,172,500 per month.

When the catch is abundant, the economic circulation on this island will also run smoothly and vice versa, if the catch of fishermen is reduced or not available at all, then the economic circulation on this island will also come to a complete standstill. However, the realization of development because the private sector can make the area more productive than usual or the addition of the Makassar City Regional Government Budget [15].

\section{Conclusion}

In conclusion, the results of this study found that marine sand mining has an impact and risk of environmental damage, such as decreased environmental carrying capacity, reduced natural resources, biodiversity, and weakened ecosystem integrity. These environmental changes greatly impact the productivity of fish income for fishermen. Fishermen's catch decreases, of course, this has something to do with changing social and economic conditions of fishermen. The phenomenon that is born is a disharmony that is very prone to causing quarrels in the household. While the economic impact, recorded a total loss of 1,043 fishermen from Kodingareng consisting of Traditional Fishing Gearmen, fishing rods, nets and arrows reached 80.4 billion rupiahs. 


\section{References}

1. Z. Ernas, M. H. Thayib, and W. S. Pranowo, J. Segara 14, (2018)

2. R. Dahuri, Mimb. J. Sos. Dan Pembang. 17, 139 (2001)

3. N. Khaerah, Z. Rusnaedy, H. Haeril, and A. Harakan, in Proc. 1st Int. Conf. Environ. Governance, ICONEG 2019, 25-26 Oct. 2019, Makassar, South Sulawesi, Indones. (EAI, 2020)

4. I. Winarwati, Konsep Negara Kepulauan (Setara Press, Jakarta, 2016)

5. H. Haeril and E. P. Purnomo, J. Local Gov. Issues 2, 18 (2019)

6. R. Lasabuda, J. Ilm. PLATAX 1, 92 (2013)

7. D. Ferrol-Schulte, P. Gorris, W. Baitoningsih, D. S. Adhuri, and S. C. A. Ferse, Mar. Policy 52, 163 (2015)

8. M. Al Amin, S. Riadi, and Didi, Oligariki Proyek Strategis Nasional Dan Kerusakan Laut Supermonde (Koalisi Save Spermonde, 2020)

9. Alisjahbana, Salsiah., and E. Murniningtyas, Tujuan Pembangunan Berkelanjutan Di Indonesia: Konsep Target Dan Strategi Implementasi (Unpad Press., Bandung, 2018)

10. K. Prianto, Al-Ard J. Tek. Lingkung. 2, 6 (2016)

11. R. S. Rivai and I. S. Anugrah, Forum Penelit. Agro Ekon. 29, 13 (2016)

12. L. Bijlsma, C. Ehler, R. Klein, S. Kulshrestha, R. Mclean, N. Mimura, R. Nicholls, L. Nurse, H. Nieto, E. Stakhiv, R. Turner, and R. Warrick, in (1995), pp. 289-324

13. S. Adiningsih, Kepala Pus. Stud. Asia Pasifik UGM (2009)

14. N. H. Woolf and C. Silver, Qualitative Analysis Using Nvivo, The Five Level QDA Method. In Routledge (New York and London: Routledge, 2018)

15. A. Annas and Z. Rusnaedy, J. Gov. Civ. Soc. 3, 117 (2019) 